\title{
Poly(L-histidine)-tagged 5-aminolevulinic acid prodrugs: new photosensitizing precursors of protoporphyrin IX for photodynamic colon cancer therapy
}

\author{
This article was published in the following Dove Press journal: \\ International Journal of Nanomedicine \\ 15 May 2012 \\ Number of times this article has been viewed
}

\section{Renjith P Johnson'* Chung-Wook Chung2* Young-II Jeong ${ }^{2}$ Dae Hwan Kang ${ }^{2}$ Hongsuk Suh ${ }^{3}$ II Kim'}

'WCU Centre for Synthetic Polymer Bioconjugate Hybrid Materials, Department of Polymer Science and Engineering, Pusan National University, Pusan, ${ }^{2}$ National Research and Development Center for Hepatobiliary Cancer, Pusan National University, Yangsan Hospital, Yangsan, Gyeongnam, ${ }^{3}$ Department of Chemistry and Chemistry Institute for Functional Materials, Pusan National University, Pusan, Korea

*These authors contributed equally to this work
Correspondence: II Kim

WCU Center for Synthetic Polymer Bioconjugate Hybrid Materials,

Department of Polymer Science and Engineering, Pusan National University,

Pusan 609-735, Korea

$\mathrm{Tel}+82515102466$

Fax +82 5I 5I 37720

Email ilkim@pusan.ac.kr
Background: 5-Aminolevulinic acid (ALA) and its derivatives have been widely used in photodynamic therapy. The main drawback associated with ALA-based photodynamic therapy (ALA-PDT) and ALA fluorescence diagnosis results from the hydrophilic nature of ALA and lack of selectivity for tumor versus nontumor cells. The application of certain triggers, such as $\mathrm{pH}$, into conventional sensitizers for controllable ${ }^{1} \mathrm{O}_{2}$ release is a promising strategy for tumor-targeted treatment.

Methods: A series of $\mathrm{pH}$-sensitive ALA-poly(L-histidine) $\left[\mathrm{p}(\mathrm{L}-\mathrm{His})_{\mathrm{n}}\right]$ prodrugs were synthesized via ring opening polymerization of 1-benzyl- $N$-carboxy-L-histidine anhydride initiated by the amine hydrochloride group of ALA itself. As an alternative to ALA for PDT, the synthesized prodrugs were used to treat a cultured human colon cancer HCT116 cell line under different $\mathrm{pH}$ conditions. The effect of ALA-p(L-His) derivatives was evaluated by monitoring the fluorescence intensity of protoporphyrin IX, and measuring the cell survival rate after suitable light irradiation.

Results: The cytotoxicity and dark toxicity of ALA and synthesized ALA-p(L-His) derivatives in HEK293T and HCT116 cells in the absence of light at $\mathrm{pH} 7.4$ and 6.8 shows that the cell viability was relatively higher than $100 \%$. ALA-p(L-His) ${ }_{n}$ showed high phototoxicity and selectivity in different $\mathrm{pH}$ conditions compared with ALA alone. Because the length of the histidine chain increases in the ALA-p(L-His) prodrugs, the PDT effect was found to be more powerful. In particular, high phototoxicity was observed when the cells were treated with ALA-p(L-His) ${ }_{15}$, compared with treatment using ALA alone.

Conclusion: The newly synthesized ALA- $\mathrm{p}$ (L-His) ${ }_{\mathrm{n}}$ derivatives are an effective alternative to ALA for enhancing protoporphyrin IX production and the selectivity of the phototoxic effect in tumor cells.

Keywords: 5-aminolevulinic acid, photodynamic therapy, poly(L-histidine), bioconjugate, cancer cells

\section{Introduction}

Photodynamic therapy (PDT) using 5-aminolevulinic acid (ALA) is gaining increasing attention in medicine as an important and effective technique for the treatment of a variety of neoplastic lesions and premalignant disorders. ${ }^{1}$ In recent years, fluorescent photodetection has received increasing attention as a new approach for the selective detection and treatment of cancer. One major mechanism is the production of the photosensitizer, protoporphyrin IX (PpIX), from the precursor, ALA. The external addition of ALA or 
its derivatives results in enhanced synthesis of porphyrin by cells. James and Pottier first described an in situ approach to the conversion of ALA, a nonphotoactivable precursor, into PpIX, a naturally occurring photosensitizing species, via the cellular heme biosynthetic pathway. ${ }^{2}$ In clinical application, when sufficient intracellular levels of PpIX are generated, the targeted tissue is irradiated by a light of suitable wavelength to activate the sensitizer and trigger a chain of events that ultimately result in cell death. At the molecular level, this involves interaction of the excited photosensitizer with molecular oxygen, leading to generation of electrophilic species (singlet oxygen and/or radicals) that cause oxidative damage to cellular constituents, such as phospholipid membranes, nucleic acids, and proteins. ${ }^{3}$

PpIX generated by exogenous ALA administration has several advantages over other types of photosensitizers, such as synthetic porphyrin or phthalocyanine derivatives that have been applied in PDT. For example, the risk of overtreatment with ALA-PDT is limited because of the fast clearance of ALA from the body, while the saturation of PpIX production at high ALA doses also prevents excessive PpIX production in tissues. ${ }^{4}$ The relatively rapid photobleaching of PpIX also means that the phototoxic effects of ALA-PDT are not persistent. ${ }^{5}$ The main drawback associated with ALA-PDT and ALA fluorescence diagnosis results from the hydrophilic nature of ALA itself. At physiological $\mathrm{pH}$, ALA is a zwitter ion; this retards its ability to cross through biological barriers such as cellular membranes, resulting in nonhomogeneous distribution in the targeted tissue. ${ }^{5}$ The selectivity of PDT is an important factor because normal cells are also able to accumulate sensitizers, which leads to prolonged skin photosensitization. Thus, an improvement in the selectivity of photosensitizers for tumor versus nontumor cells is needed.

To overcome this difficulty, several chemical approaches have been attempted to improve the incorporation and selectivity of ALA. One approach has been to use more lipophilic ALA derivatives, such as alkyl or ethylene glycol esters, which are potential substrates for cellular esterases, ${ }^{6-9}$ or different delivery systems, including dendrimers ${ }^{10-12}$ and liposomes. ${ }^{13,14}$ The use of alkyl esters of ALA results in nonspecific distribution of ALA in all cell types, but with increased PpIX production in tumor cells. ${ }^{15}$ Another approach to obtaining ALA prodrugs that have both improved physiochemical properties and can selectively release ALA in specific cell lines is to incorporate ALA into short peptide derivatives. These are stable at physiological $\mathrm{pH}$, unlike ALA and its esters. In this regard, Casas et $\mathrm{al}^{16}$ and Berger et $\mathrm{al}^{17}$ have shown that incorporation of ALA into a short peptide derivative would provide a suitable means of facilitating both transdermal delivery and improved selectivity for cancerous cells, presenting potential substrates for cell surface and cytoplasmic peptidases and/or ligands for peptide and amino acid transporters. Following this approach, Ludovic et $\mathrm{al}^{18}$ and Giuntini et $\mathrm{al}^{19}$ also showed that the incorporation of ALA into short peptide derivatives is an effective general approach for increasing cellular delivery of ALA.

The application of certain features, such as $\mathrm{pH}$ or bioaffinity, into conventional sensitizers for controllable ${ }^{1} \mathrm{O}_{2}$ release has been the subject of great interest. The selectivity of a sensitizer that produces ${ }^{1} \mathrm{O}_{2}$ at acidic $\mathrm{pH}$, but is almost deactivated at physiological $\mathrm{pH}$, would be beneficial in cancer treatment because the $\mathrm{pH}$ in growing malignant tumors tends to be somewhat lower than that in surrounding normal tissue. Very recently, Zhu et $\mathrm{al}^{20}$ showed that imidazole-modified porphyrin is a $\mathrm{pH}$-responsive sensitizer for photodynamic cancer therapy.

In order to enter cellular porphyrin biosynthetic pathways, precursor photosensitizers must be effectively internalized by target cells and processed into the photosensitizer, PpIX. In this general context, we investigated the use of novel short polypeptide-tagged ALA prodrugs to improve the uptake and cell selectivity of ALA. Poly(L-histidine) [p(L-His)] was selected because of its interesting properties; it is known to show endosomal membrane disruption activity, which is induced by the "proton sponge" mechanism of imidazole groups. ${ }^{21,22}$ The objective of the present study was to formulate PpIX from $\mathrm{p}$ (L-His)-tagged 5-ALA derivatives and to measure the resulting uptake, intracellular distribution, and effectiveness in PDT against human colon cancer (HCT116) cells under varying $\mathrm{pH}$ conditions. ALAs containing various lengths of $\mathrm{p}$ (L-His) chains were synthesized, and their PpIX generation and efficiency were investigated.

\section{Materials and methods}

ALA, 3-[4,5-dimethyl-2-thiazolyl]-2,5-diphenyltetrazolium bromide (MTT), and propidium iodide were purchased from Sigma Chemical Company (St Louis, MO). FITCannexin V was obtained from Santa Cruz Biotechnology (Santa Cruz, CA). N, N'-dimethylformamide (DMF) was distilled over sodium. 1, 4-Dioxane was purified by column chromatography on activated $\mathrm{Al}_{2} \mathrm{O}_{3}$ to remove peroxide impurities and then distilled. All other reagent grade chemicals such as $N$ - $\alpha$ - $t$-butyloxycarbonyl- $N$ im-benzyl-1-histidine (Boc-L-His (Bn)-OH) and $\mathrm{PCl}_{5}$, were purchased from Sigma and used without further purification. 
Cell culture materials were purchased from Invitrogen (Grand Island, NY).

\section{Synthesis of I-benzyl-N-carboxy- L-histidine anhydride}

Boc-His(Bn)-OH $2.5 \mathrm{~g}$ was suspended in anhydrous 1,4-dioxane $(10 \mathrm{~mL})$, to which a solution of phosphorus pentachloride $(1.8 \mathrm{~g})$ in 1,4 -dioxane $(20 \mathrm{~mL})$ was added to form $\mathrm{N}$-carboxyanhydride (NCA) at $25^{\circ} \mathrm{C}$ under stirring. Within a few minutes, a clear solution was obtained and then filtered through a glass filter. Crystals of 1-benzyl- $N$-carboxyL-histidine anhydride were obtained after the addition of the filtrate to an excess of diethyl ether. The product was subsequently washed and dried under vacuum.

\section{Synthesis of ALA-p(Bn-L-His)}

$\mathrm{p}$ (L-His)-tagged ALA derivatives were synthesized by ring opening polymerization of benzyl- $N$-carboxy-L-histidine anhydride utilizing the amino group of ALA as an initiator. Typically, ALA (0.0655 g, $0.5 \mathrm{mmoL})$ and benzyl- $N$ carboxy-L-histidine anhydride monomer $(1.35 \mathrm{~g}, 5 \mathrm{mmoL})$ were dissolved in DMF in two separate Schlenk flasks and subsequently combined using a transfer needle under nitrogen. The reaction mixture was stirred for three days at room temperature in a dark inert nitrogen atmosphere. After polymerization, the solvent was concentrated, and the DMF solution was precipitated in diethyl ether and dried under vacuum to yield ALA-p(Bn-L-His) $(n=5, n=10$, or $\mathrm{n}=15$ ).

\section{Deprotection of benzyl groups}

A round-bottomed flask was charged with a solution of ALA-p(Bn-L-His) in trifluoroacetic acid (200 mg, $3 \mathrm{~mL}$ ). Then, a four-fold molar excess of a $33 \mathrm{w} \%$ solution of $\mathrm{HBr}$ in acetic acid was added, and the reaction mixture was stirred for 2 hours at $0^{\circ} \mathrm{C}$. Finally, the reaction mixture was precipitated in anhydrous diethyl ether, and the product was subsequently dried under vacuum to yield ALA- $\mathrm{p}(\mathrm{L}-\mathrm{His})_{\mathrm{n}}$ as a yellow powder $(n=5, n=10$, or $n=15)$.

\section{Characterization}

${ }^{1} \mathrm{H}$ nuclear magnetic resonance (NMR) spectra were recorded on a Varian Unity Plus-400 spectrometer. Ultravioletvisible spectroscopic analysis was performed on a Shimadzu UV-1650 PC, and Fourier-transform infrared spectra were recorded on a Shimadzu IR Prestige 21 spectrometer at room temperature. The spectra were taken in $\mathrm{KBr}$ discs in the range of $3500-500 \mathrm{~cm}^{-1}$.
The molecular weight and polydispersity index of the products were determined by gel permeation chromatography using two Styragel columns (HT3 and HT4, Waters Company) at $40^{\circ} \mathrm{C}$. DMF containing $0.1 \mathrm{~N} \mathrm{LiBr}$ was used as a carrier solvent at a flow rate of $1.0 \mathrm{~mL} /$ minute. A Waters 1515 pump and a Waters 2414 differential refractive index detector were used. Monodispersed polystyrene polymers were used as calibration standards.

\section{Cell culture}

Human embryonic kidney (HEK293T) cells and colorectal carcinoma (HCT116) cells were cultured in RPMI 1640 medium (Gibco, Grand Island, NY) supplemented with $10 \%$ fetal bovine serum (Invitrogen) and 1\% antibiotics at $37^{\circ} \mathrm{C}$ in $5 \% \mathrm{CO}_{2}$. The cells were subcultured twice a week.

\section{Cytotoxicity}

HEK293T cells were seeded in 96-well plates at a density of $2 \times 10^{4}$ cells per well and incubated for 24 hours in 5\% $\mathrm{CO}_{2}$ at $37^{\circ} \mathrm{C}$. For the cytotoxicity test, the cells were then incubated in serum-free RPMI media for 24 hours. After removing the culture medium, the wells were washed with phosphate-buffered saline. Each well was then replaced with $100 \mu \mathrm{L}$ of fresh RPMI medium containing 0.1-1.0 mM ALA or ALA-p(L-His), and the cells were incubated in the dark at $37^{\circ} \mathrm{C}$ for 4 hours. After that, the cells were washed with phosphate-buffered saline three times and cytotoxicity was assessed using the MTT assay as described below.

\section{Dark toxicity}

HCT116 cells $\left(2 \times 10^{4}\right)$ were seeded into 96-well plates and treated with $1 \mathrm{mM}$ of ALA or ALA-p(L-His), in serum-free medium for 4 hours. After that, the medium was changed to growth medium containing $10 \%$ fetal bovine serum without irradiation and incubated. After 24 hours, the cells were washed with phosphate-buffered saline twice and cell viability was measured by MTT assay.

\section{Photodynamic treatment}

HCT116 cells were seeded in 96-well plates, cultured for 24 hours, and then washed with phosphate-buffered saline. Following this, $100 \mu \mathrm{L}$ of serum-free medium containing 1 mM ALA or ALA-p(L-His) was added to each well and the cells were incubated for 4 hours. Control wells were treated with serum-free medium in the absence of both ALA and ALA-p(L-His). The plates were then exposed to an expanded homogenous beam of $635 \mathrm{~nm}$ radiation at a dose of $1.0 \mathrm{~J} / \mathrm{cm}^{2}$ as measured by the photoradiometer. 
Immediately after irradiation, the medium was removed and the cells were washed with phosphate-buffered saline. Following this, $100 \mu \mathrm{L}$ of fresh RPMI with $10 \%$ phosphatebuffered saline was added, and the cells were incubated for a further 24 hours. Cell phototoxicity was determined by the MTT assay as described below.

\section{MTT assay}

The effect of PDT on cell proliferation was measured using a modified MTT assay. The MTT assay is based on the fact that live cells containing active mitochondria are able to cleave the tetrazolium ring to a molecule that absorbs light at $570 \mathrm{~nm}$. Cells were cultured in 96-well plates at a density of $2 \times 10^{4}$. After removal of the culture medium, $100 \mu \mathrm{L}$ of fresh medium containing $25 \mu \mathrm{L}$ MTT reagent $(2 \mathrm{mg} / \mathrm{mL}$ in phosphate-buffered saline, Sigma) was added to each well. The cells were further incubated at $37^{\circ} \mathrm{C}$ for 3 hours. The cells were then lysed with $100 \mu \mathrm{L}$ of lysis buffer solution ( $10 \%$ sodium dodecyl sulfate in $0.01 \mathrm{~N} \mathrm{HCl}$ ) for 18 hours, and the absorbance was measured at $570 \mathrm{~nm}$.

\section{Fluorescence microscopy}

PpIX products were observed using a fluorescence microscope. The microscope was equipped with a 460-480 nm excitation filter and a $610 \mathrm{~nm}$ emission filter for the detection of PpIX fluorescence. $1 \times 10^{6} \mathrm{HCT} 116$ cells were seeded on a cover slip in each well of a 6 -well plate. The cells were then treated with $1.0 \mathrm{mM}$ ALA or ALA-p(L-His) for 4 hours in serumfree media, after which the medium was discarded. The cells were then washed with phosphate-buffered saline, fixed with $4 \%$ paraformaldehyde in phosphate-buffered saline, mounted on a glass slide, and observed using a fluorescence microscope.

\section{Flow cytometry analysis}

To confirm cell death induced by PDT, at least 10,000 gated cells were studied using a FACScan flow cytometer (Becton Dickinson Biosciences, San Jose, CA). Two reagents, FITCannexin $\mathrm{V}$ and propidium iodide, were used to identify apoptosis and necrosis of the HCT116 cells, respectively. The cells were treated with $1 \mathrm{mM}$ of ALA or ALA-p(L-His) at pH 6.8 or 7.4 for 4 hours. After that, cells were irradiated at $635 \mathrm{~nm}$ with $1 \mathrm{~J} / \mathrm{cm}^{2}$, and the cells collected were washed with phosphate-buffered saline. The control cell was not treated with any kind of drugs or light. The pellets were resuspended with binding buffer (10 mM 4-(2-hydroxyethyl)1-piperazineethanesulfonic acid [HEPES] pH 7.4, $150 \mathrm{mM}$ $\mathrm{NaCl}, 5 \mathrm{mM} \mathrm{KCl}, 1 \mathrm{mM} \mathrm{MgCl}{ }_{2}, 1.8 \mathrm{mM} \mathrm{CaCl}_{2}$ ) containing
FITC-annexin V $1 \mu \mathrm{g} / \mathrm{mL}$ and incubated further for 30 minutes. Ten minutes prior to termination of incubation, propidium iodide $10 \mu \mathrm{g} / \mathrm{mL}$ was added to stain necrotic cells under dark conditions. Following that, the cells were immediately analyzed using the FACScan flow cytometer.

\section{Statistical data analysis}

Results are expressed as the means of at least parallel experiments \pm the standard deviation. Statistical data analysis was performed using the Student's $t$-test, with $P<0.05$ as the minimal level of significance.

\section{Computational details}

The density functional theory and Fukui indices calculations were performed using the $\mathrm{DMol}^{3}$ program implemented within the Materials Studio software version 4.3.1, ${ }^{23}$ a high quality quantum mechanics computer program (Accelrys, San Diego, CA). We optimized the geometry of ALA, ALA$\mathrm{p}$ (His) $)_{5}$, ALA-p(His) ${ }_{10}$, and ALA-p(His) ${ }_{15}$ in the aqueous phase. The aqueous phase was represented by the conductorlike screening model (Cosmo). ${ }^{24,25}$ We calculated the energies and geometries of the compounds using the local density approximation of Vosko-Wilk-Nausair. ${ }^{26}$ The energies were then refined by single point energy calculations using the generalized gradient approximation (PW91) of Perdew and Wang. ${ }^{27}$ Computations for all models were performed using the double numerical plus polarization basis set. ${ }^{28}$

\section{Results and discussion Synthesis of ALA-p(L-His)}

The initial step in ALA-induced synthesis of porphyrins is penetration of ALA through the plasma membrane. ALA is a hydrophilic molecule, and its hydrophilicity may be a clinical limitation for the use of ALA in PDT because of the low rate of hydrophilic drug uptake in cells and/or the poor penetration of such drugs through the tissue. ${ }^{29,30}$ Initially this problem was partly addressed by synthesis of lipophilic ester prodrugs that provide improved cellular uptake and are metabolized into PpIX following the action of nonspecific intracellular esterases. A more recent development concerns the preparation of peptide-based ALA prodrugs. ${ }^{16-19,31}$ This approach describes the synthesis and evaluation of short ALA peptide derivatives in which either the amino or the carboxyl function of the latter is masked, thereby providing improved physical properties and the potential for cell linespecific ALA release.

Among these, poly(L-His) is found to be an excellent candidate because of its ability to confer tailored lipophilicity 
and water solubility to the prodrugs. The physiologically relevant $\mathrm{pH}$ range is 5.0-7.4; prodrugs in which protonation occurs within this $\mathrm{pH}$ range are suitable for fabricating pH-sensitive drugs for cellular level internalization. Importantly, the fusogenic activity of $\mathrm{p}$ (L-His) could disrupt the membrane envelope of acidic subcellular compartments such as endosomes, thus enhancing the delivery efficiency of the drug/nucleic acids to the cytosol. ${ }^{32}$

It is well known that a primary amine or amine hydrochloride group can initiate the polymerization of alpha amino acid $N$-carboxyanhydride. ${ }^{33}$ In this study, as an alternative approach, we utilized the amine hydrochloride functionality of ALA for the synthesis of modified prodrugs. The synthesized $\mathrm{pH}$-sensitive ALA-p(L-His) prodrugs are more lipophilic than ALA but are still water-soluble. The synthesis procedure for the prodrugs is shown in Figure 1.

The protective benzyl side chains were removed by treating ALA-p(Bn-His) $)_{n}$ with $\mathrm{HBr} / \mathrm{AcOH}$ in trifluoroacetic acid, and the resulting product was characterized by gel permeation chromatography and various spectroscopic techniques. The ${ }^{1} \mathrm{H}$ NMR spectra of ALA-p(L-His) are shown in Figure 2.

Gel permeation chromatography traces, as well as ultraviolet-visible and Fourier transform infrared spectra, are shown in the supplementary data (see Figures S1-S3). The molecular weight of ALA-p(L-His) as measured by gel permeation chromatography shows a slight overestimation of the molecular weight, even though the molecular weight calculated from ${ }^{1} \mathrm{H}$ NMR agrees with the theoretical value. After deprotection, the peak integral ratio of the methylene proton of ALA $(\delta=3.8 \mathrm{ppm})$ and $(\mathrm{O}=\mathrm{C}-\mathrm{CH}-)$ in the peptide block ( $\delta=4.95 \mathrm{ppm}$ ) was used to calculate $M_{n}$, confirming that there was no loss of the histidine repeating units during deprotection. Therefore, we can ascertain that polymerization of Bn-His-NCA and deprotection of the benzyl groups were successfully accomplished using ALA as the initiator.

\section{Computational study}

The reactivity of a compound is considered to be closely related to its frontier molecular orbitals, ie, the highest occupied molecular orbital (HOMO) and the lowest unoccupied molecular orbital (LUMO). Higher HOMO energy $\left(E_{\text {номо }}\right)$ of the molecule means a higher electron-donating capability to appropriate acceptor molecules with a low-energy empty molecular orbital and thus explains the interaction between molecules by way of delocalized pairs of electrons. The energy of the LUMO ( $\left.E_{\text {LUMO }}\right)$ standardizes the electronaccepting tendency of a molecule. Accordingly, $E_{\text {LUMO }}$, $E_{\text {номо }}$, the electronic charge on nitrogen and oxygen atoms, and the total energy of molecule $\left(E_{\mathrm{T}}\right)$ were determined and compared. The global hardness $(\eta)$ could also be estimated from the HOMO-LUMO gap because it is approximated as $\Delta E / 2,{ }^{34}$ and can be defined under the principle of chemical hardness and softness. ${ }^{35}$ These parameters also provide information about the reactive behavior of molecules and are shown in Table 1.

Because exogenous ALA-mediated accumulation of PpIX occurs in the aqueous phase, it is necessary to include the effect of water in the computational calculations. In a similar way, it is important to take into account the effects

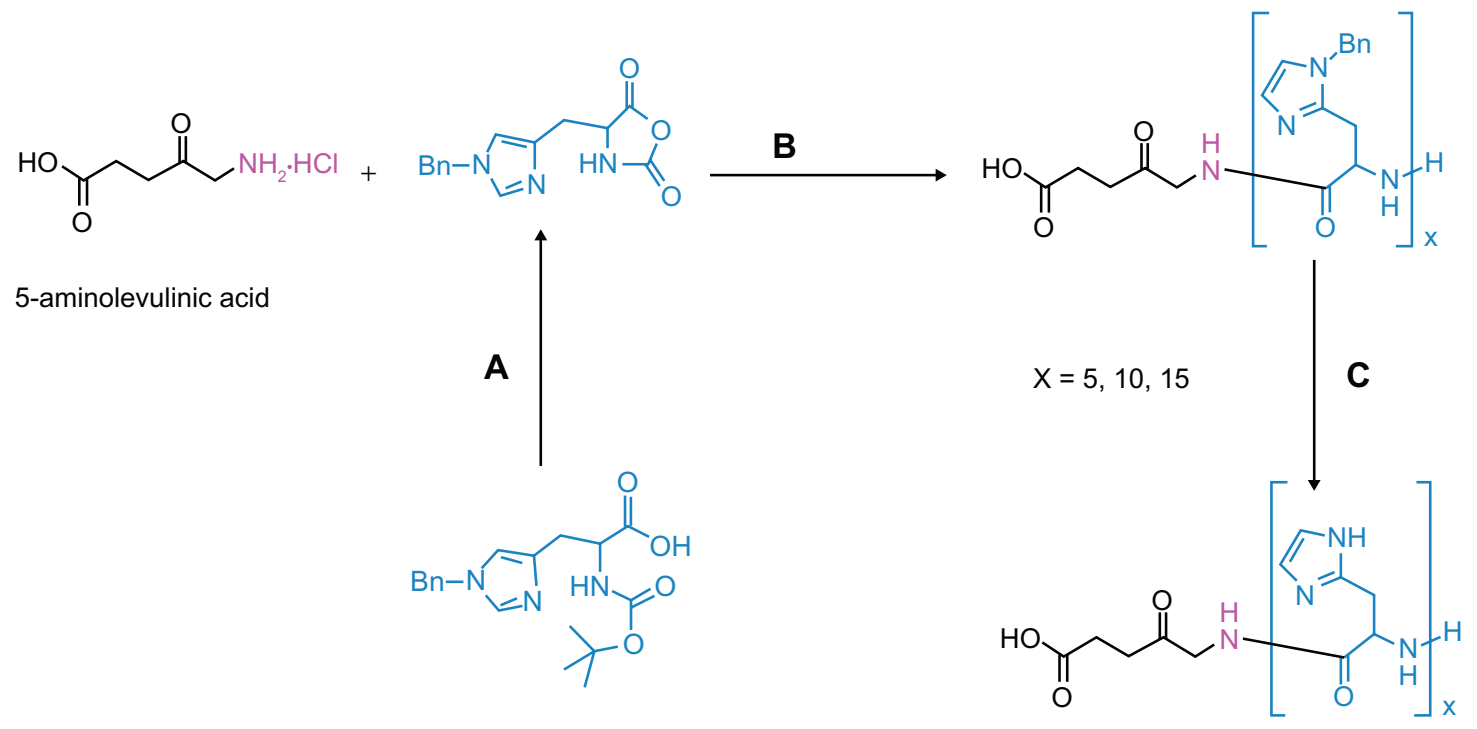

Figure I Synthesis procedures of ALA-p(His) by ring-opening polymerization of Bn-His-NCA, followed by deprotection: (A) PCl, I,4-dioxane; (B) N, N'-dimethylformamide; and $(\mathrm{C}) \mathrm{HBr} / \mathrm{AcOH}, \mathrm{TFA}$ at $0^{\circ} \mathrm{C}$. 


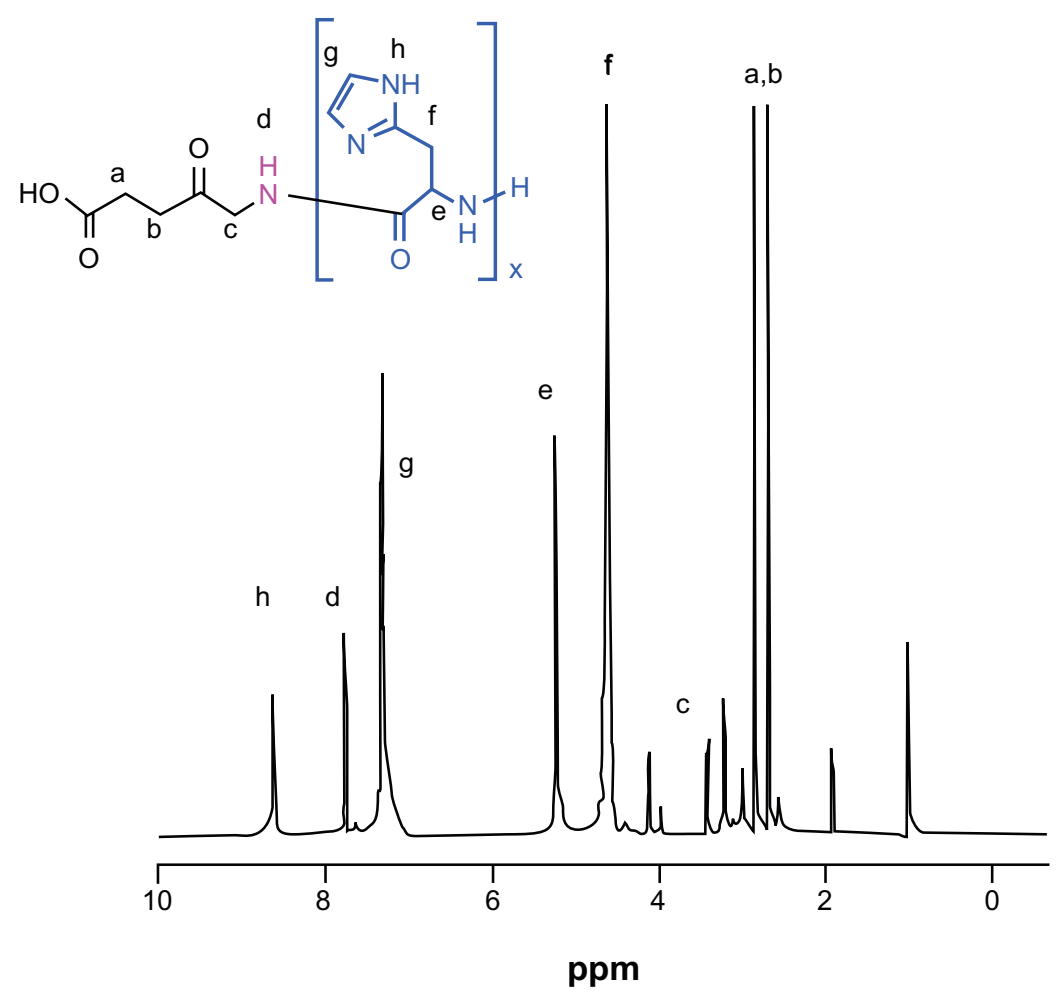

Figure $2^{\prime} \mathrm{H}$ nuclear magnetic resonance spectra of ALA- $p(\mathrm{His})_{15}$ in dimethyl- $d_{6}$ sulfoxide at $25^{\circ} \mathrm{C}$. Abbreviation: ALA, 5-aminolevulinic acid.

that can appear as much in the geometric properties as in the electrical ones. $\mathrm{Dmol}^{3}$ includes certain $\mathrm{COSMO}^{36}$ controls, which allows for solvation effects. The COSMO is a continuum solvation model in which the solute molecule forms a cavity within the dielectric continuum of permittivity, and $\varepsilon$ represents the solvent. The solvent molecules are modeled as a continuous uniform dielectric constant $(\varepsilon=78.39$ for water) and the solute is placed in a cavity within it. ${ }^{34}$ The cavity surface (or solvent-accessible surface) is obtained as a superimposition of spheres centered at the atoms, discarding all parts lying on the interior part of the surface. ${ }^{24}$ The spheres are represented by a discrete set of points, ie, the so-called basic points. Eliminating the parts of the spheres that lie within the interior part of the molecule thus amounts to eliminating the basic grid points that lie in the interior of the molecule. The radii of the spheres are determined as the sum of the van der Waals radii of the atoms of the molecule and of the probe radius. The surviving basic grid points are then scaled to lie on the surface generated by the spheres of van der Waals radii alone. The basic points are then collected into segments, which are also represented as discrete points on the surface. The screening charges are located at the segment points. The results for the solvent-accessible surface, total and solvation energies, HOMO and LUMO orbital energies, $\Delta E$, and $\eta$, calculated for ALA, ALA-p(His) $)_{5}$, ALA-p(His) ${ }_{10}$, and ALA-p(His $)_{15}$ in the aqueous phase, are shown in Table 1.

Table I Molecular properties of ALA and ALA-p(His) molecules calculated using the density functional theory method in the aqueous phase

\begin{tabular}{|c|c|c|c|c|}
\hline & ALA & ALA-p(His) $)_{5}$ & ALA-p(His) $)_{10}$ & ALA-p(His) $_{15}$ \\
\hline Total energy $(\mathrm{Ha})$ & -476.018 & -2834.929 & -5158.953 & -7502.025 \\
\hline Solvation energy $(\mathrm{Ha})$ & -0.030 & -0.147 & -0.190 & -0.186 \\
\hline Surface area of cavity $\left[\AA^{2}\right]$ & 158.350 & 709.697 & 922.325 & 1209.550 \\
\hline Total volume of cavity $\left[\AA^{3}\right]$ & 147.286 & 840.290 & $14 \mid 5.375$ & 2035.672 \\
\hline LUMO (eV) & -5.472 & -4.959 & -5.310 & -5.163 \\
\hline HOMO (eV) & -1.532 & -1.876 & -1.894 & -2.257 \\
\hline$\Delta \mathrm{E}=\left(\mathrm{E}_{\text {LUMO }}-\mathrm{E}_{\text {HоMO }}\right)$ & 3.940 & 3.083 & 3.416 & 2.906 \\
\hline$\eta=\Delta \mathrm{E} / 2$ & 1.970 & 1.542 & 1.708 & 1.453 \\
\hline
\end{tabular}

Abbreviations: ALA, 5-aminolevulinic acid; HOMO, highest occupied molecular orbital; LUMO, lowest occupied molecular orbital. 
The optimized geometries, including the cavity surface of the compounds as well as the HOMO and LUMO molecular orbitals, are shown in Figure 3.

As expected, the surface area and volume of the cavity increase as the size of the molecule increases from ALA to ALA-p(His) $)_{15}$. Global hardness is a parameter that gives important information about the reactive behavior of the molecule. The ALA molecule shows the maximum hardness value, and decreases in order of ALA-p(His) $)_{10}>$ ALA$\mathrm{p}(\mathrm{His})_{5}>$ ALA- $\mathrm{p}(\mathrm{His})_{15}$. The ALA molecule has the highest
$E_{\text {номо }}$ and lowest $E_{\text {LUMO }}$, which explains the higher tendency of the molecule to donate electrons as well as accept electrons from neighboring water molecules. These values can change significantly by conjugating $\mathrm{p}$ (His) units to the ALA molecule. In addition, HOMO moves from the nitrogen atom of the ALA molecule to the nitrogen atoms of the histidine rings in ALA-p(His) molecules. This would indicate that the preferred active sites for electrophilic attack are located within the region around the nitrogen atoms belonging to the histidine rings, before the $\mathrm{p}$ (His) units dissociate

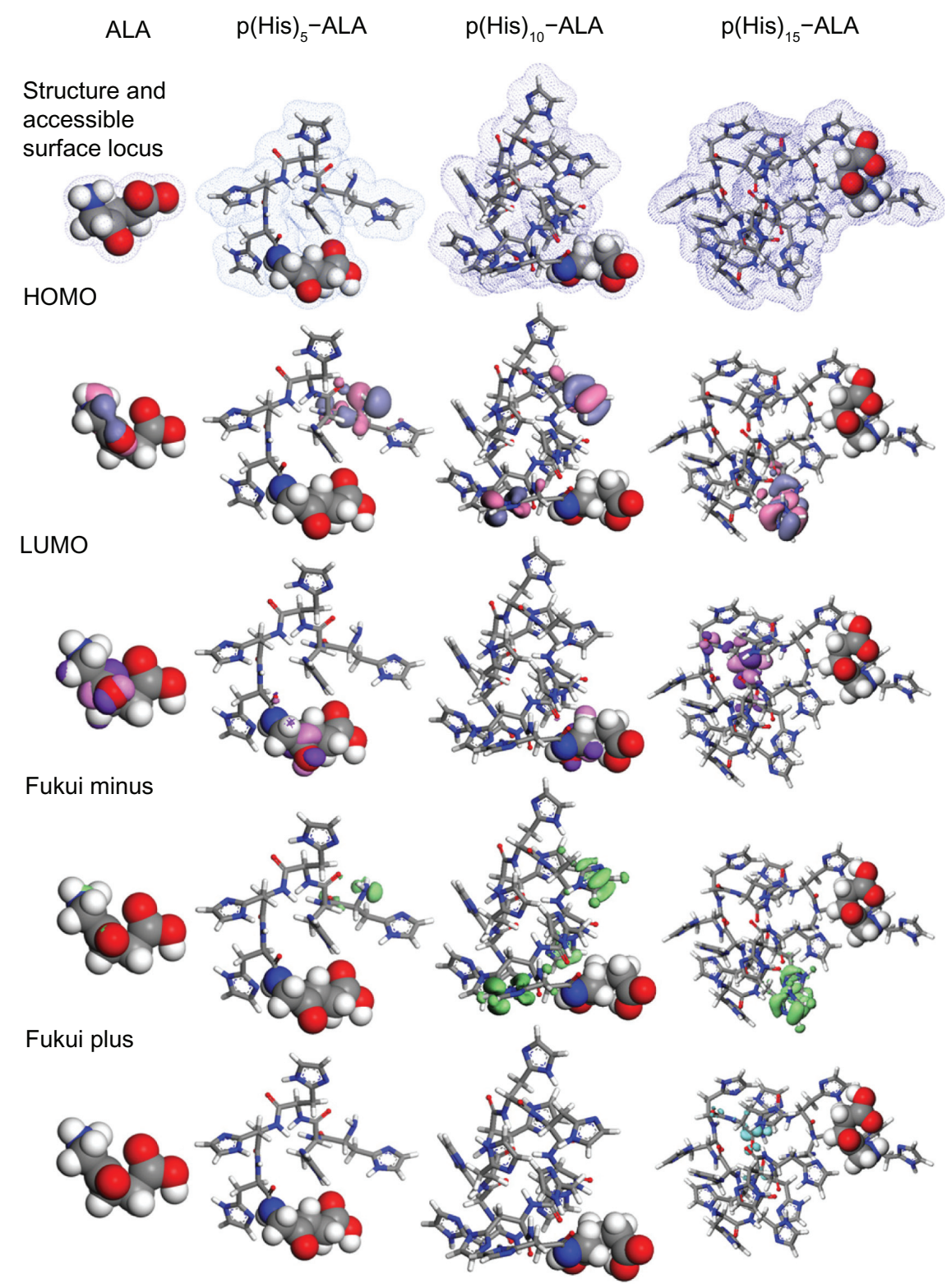

Figure 3 Geometry optimized structure of ALA and ALA-p(His), molecular orbital plots as well as Fukui active sites for electrophilic and nucleophilic attack on ALA and ALA-p(His) molecules.

Note: The density functional theory and Fukui indices calculations were performed in the aqueous phase.

Abbreviations: ALA, 5-aminolevulinic acid; HOMO, highest occupied molecular orbital; LUMO, lowest occupied molecular orbital. 
from ALA-p(His) conjugates. These differences in $\Delta E$ and positions of HOMO and LUMO result in wide variations in solubility in water, especially in different $\mathrm{pH}$ conditions and with light-induced accumulation of PpIX. The solvation energy, ie, change in Gibbs energy when a molecule is transferred from a vacuum to a solvent, decreases sharply after $\mathrm{p}$ (His) units are conjugated to an ALA molecule. Considering that the main contributions to the solvation energy come from the cavitation energy of formation of the hole which preserves the dissolved species in the solvent, the orientation energy of partial orientation of the dipoles, the isotropic interaction energy of electrostatic and dispersion origin, and the anisotropic energy of specific interactions, eg, hydrogen bonds and donor-acceptor interactions, the ALA molecule is expected to show quite different behavior in water from the ALA-p(His) molecules.

Among the theoretical models proposed to compute local reactivity indices is the Fukui functions that make it possible to rationalize the reactivity of individual molecular orbital contributions, and thus to account for the response of the whole molecular spectrum, not just that of the frontier orbitals. Several benchmark applications of this protocol, describing selectivity and reactivity by means of orbital Fukui indices, have been presented by Mineva et al. ${ }^{37}$ With the purpose of having a wider knowledge about the local reactivity of ALA and ALA-p(His) hybrids, Fukui indices for each one of the atoms in the molecules have been calculated. Analysis of the Fukui indices, along with the distribution of charges and global hardness, provides a more complete scheme of the reactivity of the studied molecules. ${ }^{38}$ Fukui indices calculated for all the neutral atoms of ALA and each of the three ALA-p(His) hybrids are shown in Figure 2. It has been shown that local electron densities or charges are important in many chemical reactions and physicochemical properties of a compound. ${ }^{39}$ Frontier orbital electron densities on atoms provide a useful means for detailed characterization of donor-acceptor interactions. For finite systems such as ALA and ALA-p(His) hybrid molecules, when the molecule is accepting electrons, one has a Fukui plus charge $\left(f_{k}^{+}\right)$, ie, the index for nucleophilic attack; when the molecule is donating electrons, one has a Fukui minus charge $\left(f_{k}^{-}\right)$, ie, the index for electrophilic attack. An analysis of Fukui indices shows that, for ALA-His hybrid molecules, the nitrogen atoms in the histidine ring are more susceptible sites for electrophilic attack than those in the ALA units. The value of $f_{k}^{+}$was almost negligible for all the molecules, indicating insensitivity to nucleophilic attack.

\section{Cytotoxicity and dark toxicity of prodrugs}

To investigate the effect of ALA-p(L-His) as an alternative to ALA for PDT, HCT116 human colon cancer cells were used as a model cancer cell line. To confirm if the cell death effect was caused only by photoinduced cytotoxicity, the cytotoxicity and dark toxicity of ALA and the synthesized ALA-p(L-His) derivatives were carried out at pH 7.4 and 6.8 in HEK293T and HCT116 cells in the absence of light. As shown in Figure 4, the viability of HEK293T and HCT116 cells in the presence of $1 \mathrm{mM}$ ALA or the ALA-p(L-His) derivatives was relatively higher than $100 \%$; the prodrugs themselves did not affect cell survival. This result indicates that the effect of ALA and ALA-p(LHis)-based PDT on HCT116 cells is dependent on the production of PpIX from the prodrugs in the tumor cells, not on the prodrugs themselves. This clearly shows that ALA and ALA-p(L-His) derivatives promote cell proliferation, and do not affect cell survival in the absence of irradiation at concentrations below $1 \mathrm{mM}$.

\section{Photodynamic therapy}

The effect of ALA-p(L-His)-based PDT was evaluated by treating HCT116 cells with a concentration of $1 \mathrm{mM}$ of the prodrug for 4 hours in the dark. After irradiation, the cell survival percentage, compared with control cells, was estimated using the MTT assay. From Figure 5, it is clear that ALA-p(L-His) ${ }_{n}$ has high phototoxicity compared with ALA. Because the length of the histidine chain increases in the ALA-p(L-His) prodrugs, the PDT effect was found to be more powerful. In particular, high phototoxicity was observed when the cells were treated with ALA-p(L-His) ${ }_{15}$ compared with treatment using ALA alone. In addition, phototoxicity was higher when the cells were incubated with ALA-p(L-His) $)_{10}$ and ALA-p(L-His $)_{15}$ at lower $\mathrm{pH}$ than at the physiological $\mathrm{pH}$ of 7.4. The imidazole ring $\left(\mathrm{pK}_{\mathrm{b}}\right.$ about 6.5$)$ of $\mathrm{p}(\mathrm{L}-\mathrm{His})$ has lone pairs of electrons that endow it with $\mathrm{pH}$-dependent amphoteric properties. Protonation was seen to occur just below physiological $\mathrm{pH}$, indicating that the histidine unit attached to the ALA-p(LHis) $)_{n}$ prodrugs can act as a proton receptor and consequently effect internalization into the tumor cells. Both charged and uncharged forms of histidine are present in $\mathrm{p}(\mathrm{His})$ at neutral $\mathrm{pH}$, and the concentration ratio of the charged form to the uncharged form is very sensitive to small changes in $\mathrm{pH}$ under physiological conditions. ${ }^{40}$ Moreover, the ionization of $\mathrm{p}$ (L-His) switches the nature of the material to becoming 
A

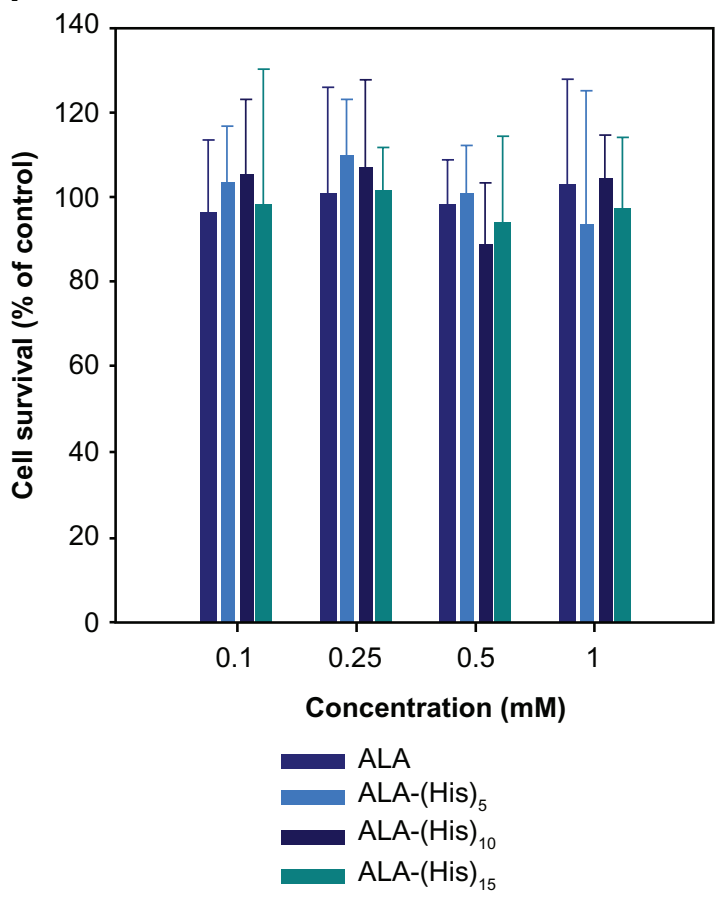

B

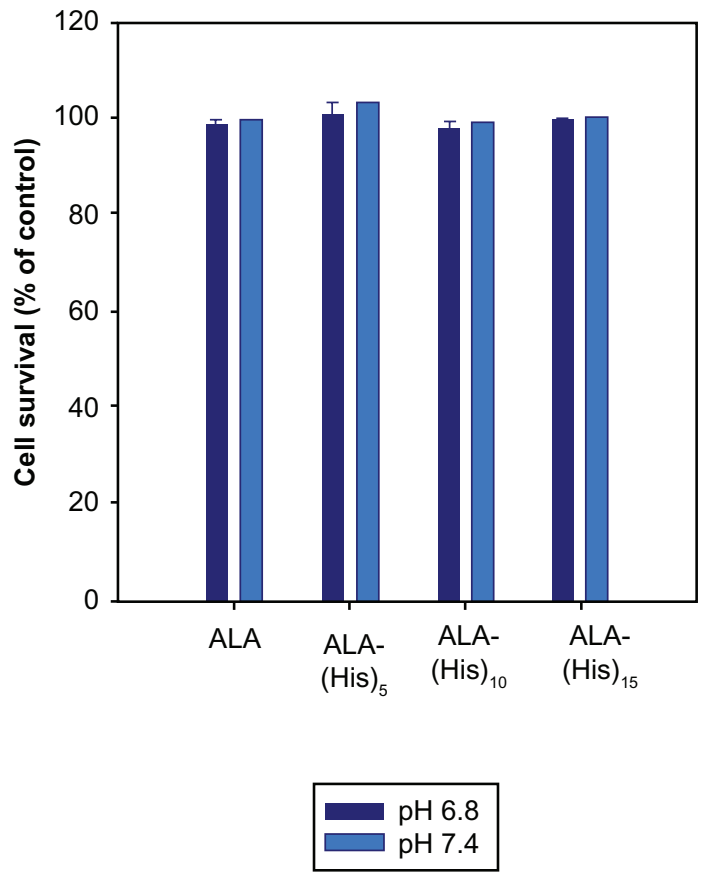

Figure 4 (A) Cytotoxicity of ALA and ALA-p(L-His) prodrugs in HEK293T cells. After 24 hours of starvation, the cells were treated with $0.1-1.0$ mM of each ALA prodrug for 4 hours. Cell viability was determined by the MTT assay. (B) Cellular dark toxicity of ALA and ALA-p(L-His) prodrugs at I mM concentration in HCTII6 cells at $\mathrm{pH} 6.8$ and 7.4. After cultivation in a 96 -well plate, the cells were treated with $1.0 \mathrm{mM}$ of each ALA prodrug for 4 hours. Cell viability was determined by the MTT assay. Abbreviations: ALA, 5-aminolevulinic acid; P(L-His), poly(L-histidine).

more lipophilic, and p(L-His) shows strong endosomolytic properties by its proton sponge effect and/or its interaction with anionic phospholipids comprising the endosomal compartments. ${ }^{22}$

The low $\mathrm{pH}$ value in the interstitial fluid in most tumors certainly plays a significant role, because many of the tumorlocalizing photosensitizers are protonated, become more lipophilic, and accumulate faster in cells upon lowering the $\mathrm{pH}$ of the incubation medium. Application of ALA or ALA$\mathrm{p}(\mathrm{L}-\mathrm{His})_{\mathrm{n}}$ leads to accumulation of the PpIX photosensitizer in tumors. Low levels of ferrochelatase activity and high levels of porphobilinogen deaminase activity have been found in malignant cells and tissues, ${ }^{41-43}$ which may contribute to the observed tumor selectivity of PpIX.44,45

As described above, the endocytosis rate of ALA$\mathrm{p}$ (L-His) derivatives in tumor cells initially increases in acidic $\mathrm{pH}$, and it is expected that the differences in phototoxicity under different $\mathrm{pH}$ conditions is due to the proton sponge effect of the $\mathrm{p}(\mathrm{L}-\mathrm{His})$ residues and is a consequence of the $\mathrm{pH}$ dependency of porphobilinogen deaminase in malignant cells and tissues. This phenomenon was clearly observed for all the prodrugs, and was stronger with increasing lengths of the histidine tag.

\section{PpIX production by ALA and $\mathrm{P}(\mathrm{L}-\mathrm{His})-\mathrm{ALA}$}

PpIX accumulation in HCT116 cells, induced by a 4-hour treatment with $1 \mathrm{mM}$ each of ALA and ALA-p(L-His) ${ }_{15}$, was observed by fluorescence microscopy. As shown in Figure 6, red fluorescence was observed in cells treated with ALA-p(LHis) $)_{n}$ prodrugs, whereas a slight or no fluorescence signal were observed in the ALA-treated and control groups, respectively. These results indicate that the administered prodrugs were successfully converted to PpIX in HCT116 cells. We found that $\mathrm{p}$ (L-His) itself has fluorescence to some degree, therefore it is difficult to know the exact amount of intracellular PpIX in the exit (data not shown). However, comparing the fluorescence image like dark toxicity and phototoxicity, it is clear that the synthesized ALA-p(L-His) prodrugs do not have any cytotoxicity or dark toxicity in either normal cells or cancer cell lines. Therefore, the death phenomenon in cancer cells was only observed after irradiation at $1.0 \mathrm{~J} / \mathrm{cm}^{2}$ of light. Moreover, from the fluorescence images, we found that the fluorescence intensity became stronger at lower $\mathrm{pH}$ conditions with ALA-p(L-His) prodrugs. This result is correlated with phototoxicity data from the synthesized prodrugs, ie, cell survival is lower in physiological condition 


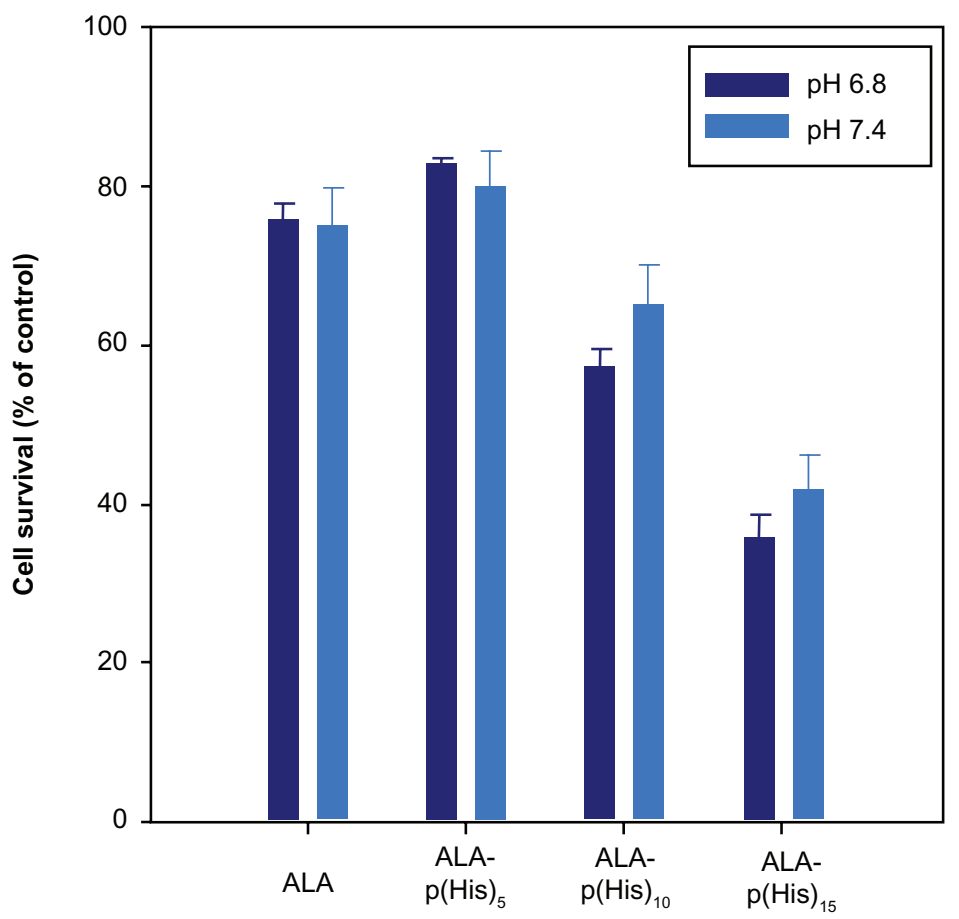

Figure 5 The photodynamic effect of ALA and ALA-p(L-His) prodrugs ( I mM concentration) on HCTII 6 cells at pH 7.4 and 6.8 . I00 $\mu \mathrm{L}$ of serum-free medium containing $1.0 \mathrm{mM}$ prodrugs was added to HCTII6 cells following incubation for 4 hours.

Notes: The control was treated with serum-free medium in the absence of both ALA and P(L-His)-ALA. After irradiation at a dose of I.0 J/cm², the medium was removed and washed with phosphate-buffered saline. Next, a fresh $100 \mu \mathrm{L}$ of RPMI with $10 \%$ phosphate-buffered saline was added and the cells were incubated for a further 24 hours. Cell phototoxicity was determined by MTT assay.

Abbreviations: ALA, 5-aminolevulinic acid; P(L-His), poly(L-histidine).

in lower $\mathrm{pH}$ condition. The fluorescence images of cells treated with ALA-p(L-His) prodrugs or ALA for 4 hours showed that ALA-p(L-His) prodrugs are potentially strong photosensitizers, dependent on the environmental conditions of the culture, ie, $\mathrm{pH} 6.8$ or $\mathrm{pH} 7.4$.

\section{Necrosis induced by ALA or $\mathrm{P}(\mathrm{L}-\mathrm{His})-\mathrm{ALA}$ PDT}

After ALA or ALA-p(L-His) $)_{n}$-based PDT, tumor cells were stained with FITC-annexin $\mathrm{V}$ and propidium iodide to visualize apoptotic cells (Figure 7A) and necrotic cells
ALA
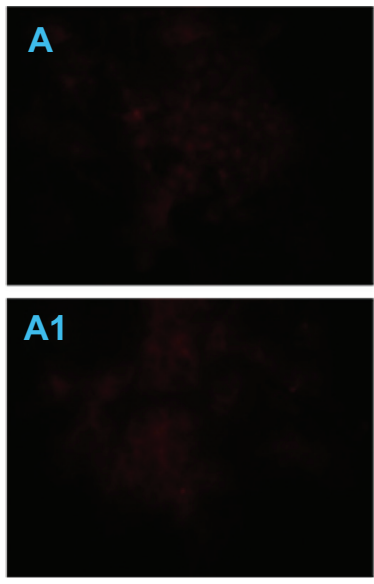

ALA-p(His $)_{5}$

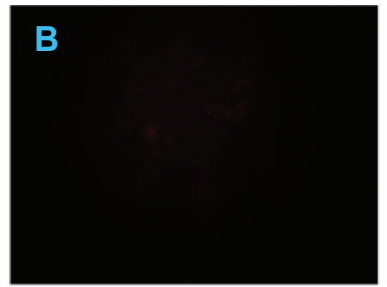

A2

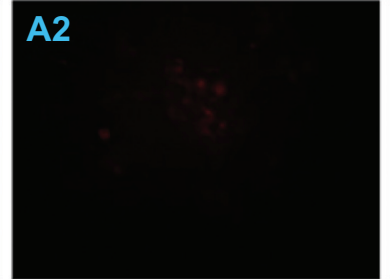

ALA-p(His) ${ }_{10}$

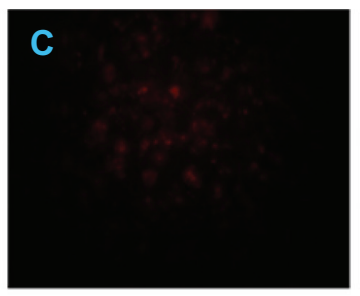

A3

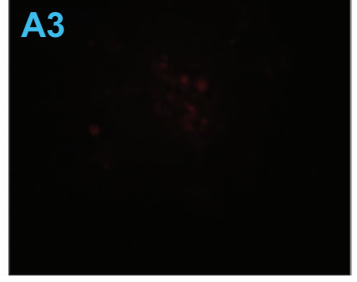

ALA-p(His) $)_{15}$

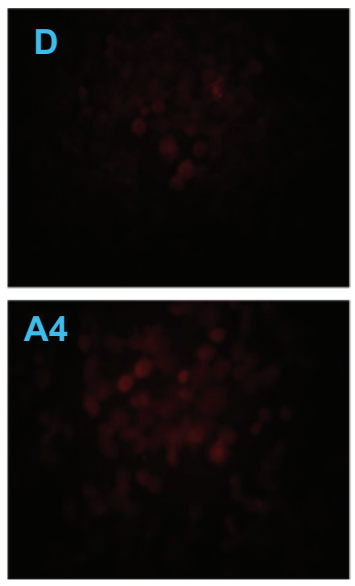

Figure 6 Fluorescence microscopic images of protoporphyrin IX accumulation from ALA and ALA-poly(L-histidine) prodrugs in HCTII6 cells at pH 7.4 (A-D) and at pH 6.8 (AI-A4). HCTII 6 cells were treated with $1.0 \mathrm{mM} \mathrm{ALA}$ or poly(L-histidine)-ALA for 4 hours in serum-free media.

Note: The cells were fixed by $4 \%$ paraformaldehyde in phosphate-buffered saline and the cells were observed using a fluorescence microscope. Abbreviation: ALA, 5-aminolevulinic acid. 


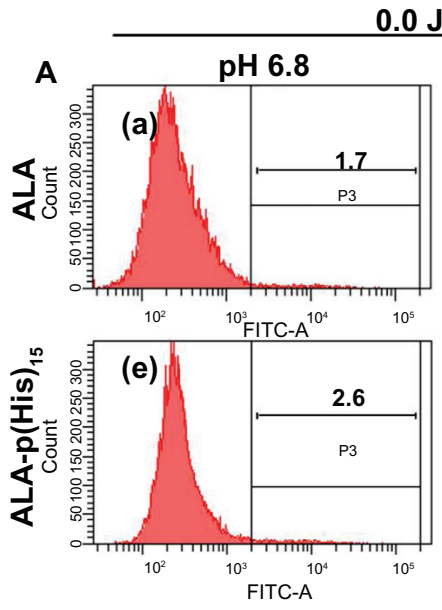

$0.0 \mathrm{~J} / \mathrm{cm}^{2}$
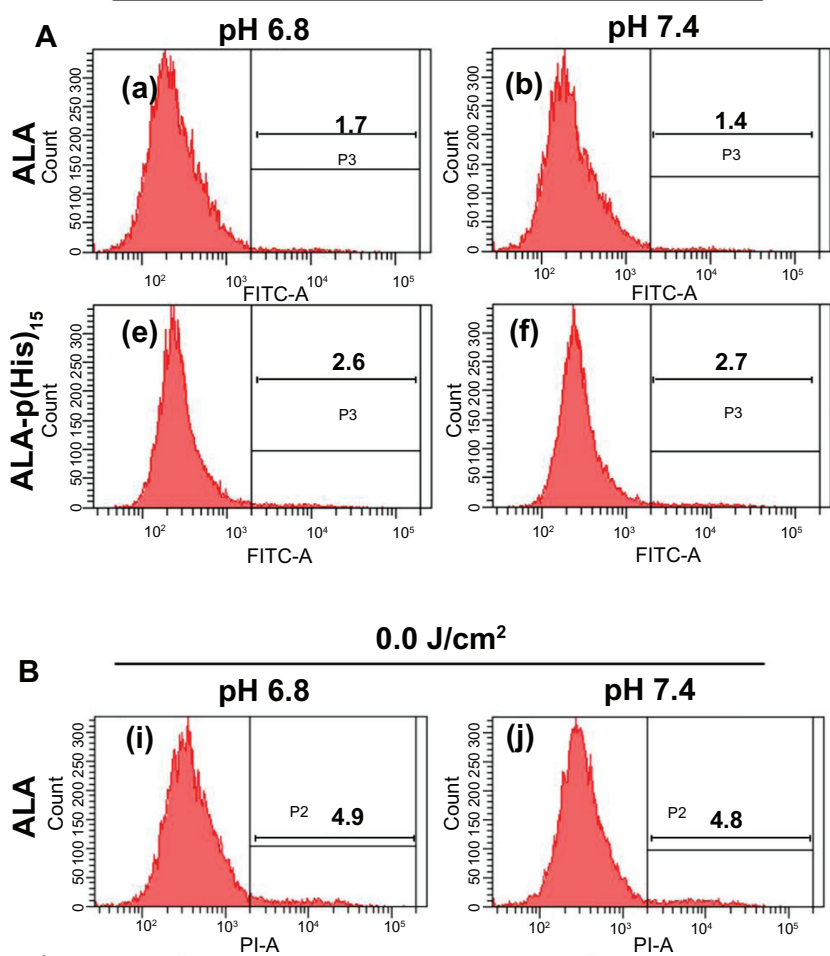

$0.0 \mathrm{~J} / \mathrm{cm}^{2}$

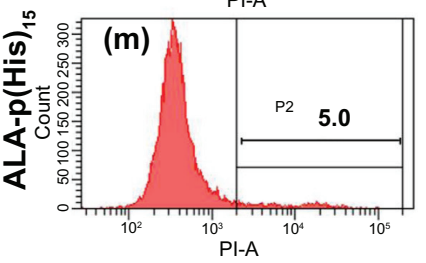

\section{$\mathrm{pH} 7.4$}
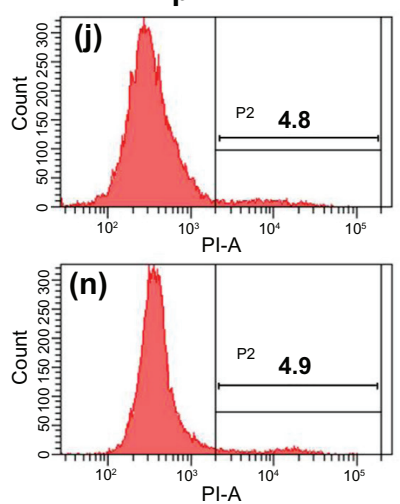

$1.0 \mathrm{~J} / \mathrm{cm}^{2}$
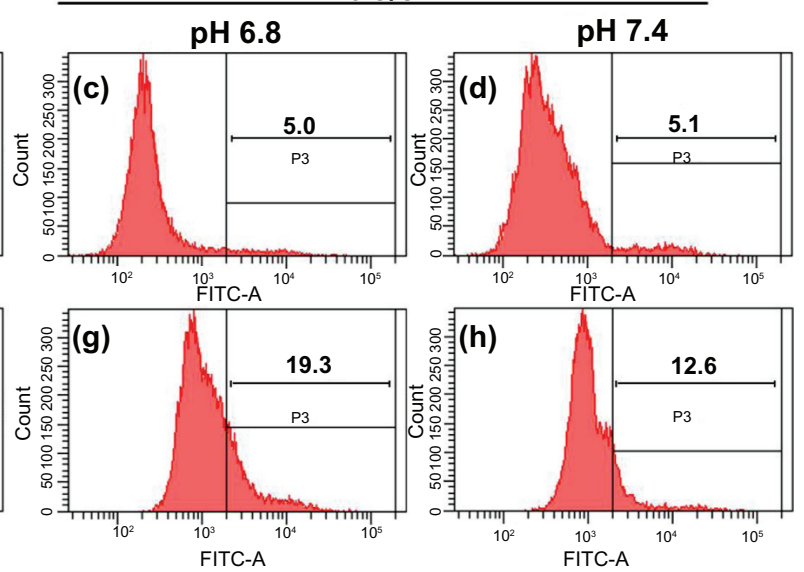

$1.0 \mathrm{~J} / \mathrm{cm}^{2}$
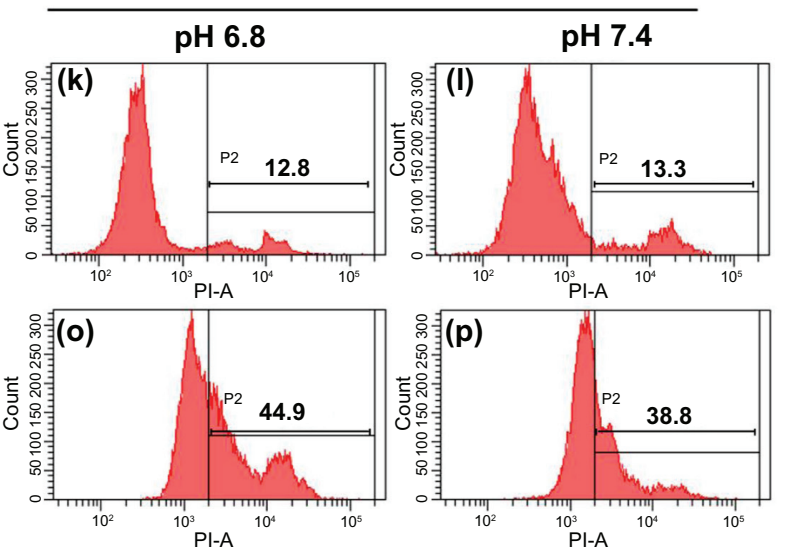

Figure 7 Apoptosis and necrosis induced by ALA or ALA-p(L-His) ${ }_{15}$ photodynamic therapy in HCTI I 6 cells at pH 7.4 and 6.8. After prodrugs or nontreatment for 4 hours, HCT cells were illuminated at $635 \mathrm{~nm}$. Cells were stained with FITC-annexin V $(\mathbf{A})$ and propidium iodide (B), then analyzed using a flow cytometer.

Note: The number in the each square is the percentage of cells in the P2 or P3 population area of total cells.

Abbreviations: ALA, 5-aminolevulinic acid; $\mathrm{P}(\mathrm{L}-\mathrm{His})$, poly(L-histidine).

(Figure 7B), respectively. As shown in Figure 7, the number of apoptotic cells gradually increased in acidic $\mathrm{pH}$ and with ALA-p(L-His $)_{15}$. Furthermore, the number of necrotic cells also dramatically increased according to the culture environment or prodrug, and necrosis of the tumor cells was dominant over apoptosis.

The proportion of apoptotic cells was estimated to be about $5.1 \%$ when they were treated with ALA alone. The same phenomenon was observed in the necrotic cells (approximately 13\%). The proportions of apoptotic and necrotic cells in the ALA-treated groups show similar populations regardless of culture $\mathrm{pH}$. In ALA-based PDT, phototoxicity was induced by apoptosis or necrosis and environmental $\mathrm{pH}$ did not affect the cell death signals. A distinct phenomenon was observed in the newly synthesized prodrugtreated groups. The proportion of apoptotic and necrotic cells increased from $12 \%$ to $19 \%$ and $38 \%$ to $45 \%$, respectively, when treated with ALA-p(L-His) ${ }_{15}$ at $\mathrm{pH}$ 6.8. These results indicate that PDT based on both ALA and ALA-p(L-His) induced death of HCT116 cells via apoptosis and necrosis, and, furthermore, that $\mathrm{pH}$-sensitive cell death was induced during ALA-p(L-His) -based PDT.

\section{Conclusion}

We propose a new system with an easy synthetic approach involving the use of $\mathrm{p}$ (His) tags on ALA to improve PDT selectivity in the treatment of cancer. P(His)-based ALA prodrugs did not show any cytotoxicity when administered to HCT 116 cells for 4 hours. The prodrug showed phototoxicity even if administered for a short time (4 hours), and this phenomenon was significantly higher in the ALA-p(L-His) ${ }_{15}^{-}$ treated group than in the control group. It is believed that the increased phototoxicity of these prodrugs at different $\mathrm{pH}$ conditions is due to the proton sponge effect of the $\mathrm{p}(\mathrm{L}-\mathrm{His})$ residues and is a consequence of the high activity of porphobilinogen deaminase in malignant cells and tissues under 
the $\mathrm{pH}$ conditions found in culture. The newly synthesized ALA-p(L-His) derivatives are considered to be an effective alternative to ALA for enhancing PpIX production and the selectivity of the phototoxic effect in tumor cells.

\section{Acknowledgments}

This work was supported by grants-in-aid for the World Class University Program (R32-2008-000-10174-0), the National Core Research Center Program from MEST (R15-2006-02201001-0), and a grant from the Korea Healthcare Technology R and D Project, Ministry for Health Welfare and Family Affairs, Republic of Korea (A091047).

\section{Disclosure}

The authors report no conflicts of interest in this work.

\section{References}

1. Barbara K, Kristjan P. ALA and its clinical impact, from bench to bedside. Photochem Photobiology Sci. 2008;7(3):283-289.

2. James CK, Pottier RH. New trends in photobiology: endogenous protoporphyrin IX, a clinically useful photosensitizer for photodynamic therapy. J Photochem Photobiol B. 1992;14(4):275-292.

3. Kennedy JC, Pottier RH, Pross DC. Photodynamic therapy with endogenous protoporphyrin: IX: basic principles and present clinical experience. J Photochem Photobiol B. 1990;6(1-2):143-148.

4. Blume JE, Oseroff AR. Aminolevulinic acid photodynamic therapy for skin cancers. Dermatol Clin. 2007;25(1):5-14.

5. Peng Q, Warloe T, Moan J, et al. Distribution of 5-aminolevulinic acid-induced porphyrins in noduloulcerative basal cell carcinoma. Photochem Photobiol. 1995;62(5):906-913.

6. Kloek J, Beijersbergen VH. Prodrugs of 5-aminolevulinic acid for photodynamic therapy. Photochem Photobiol. 1996;64(6):994-1000.

7. Gaullier JM, Berg K, Peng Q. Use of 5-aminolevulinic acid esters to improve photodynamic therapy on cells in culture. Cancer Res. 1997; 57(8):1481-1486.

8. Uehlinger P, Zellweger M, Wagnieres G. 5-aminolevulinic acid and its derivatives: physical chemical properties and protoporphyrin IX formation in cultured cells. J Photochem Photobiol B. 2000;54(1): 72-80.

9. Berger Y, Greppi A, Siri O, et al. Ethylene glycol and amino acid derivatives of 5-aminolevulinic acid as new photosensitizing precursors of protoporphyrin IX in cells. J Med Chem. 2000;43(25):4738-4746.

10. Battah SH, Chee CE, Nakanishi H. Synthesis and biological studies of 5-aminolevulinic acid-containing dendrimers for photodynamic therapy. Bioconjug Chem. 2001;12(6):980-988.

11. Di Venosa GM, Casas AG, Battah S. Investigation of a novel dendritic derivative of 5-aminolaevulinic acid for photodynamic therapy. Int J Biochem Cell Biol. 2006;38(1):82-91.

12. Battah S, O’Neill S, Edwards C. Enhanced porphyrin accumulation using dendritic derivatives of 5-aminolaevulinic acid for photodynamic therapy: an in vitro study. Int J Biochem Cell Biol. 2006;38(8): 1382-1392.

13. Casas A, Perotti C, Saccoliti M. ALA and ALA hexyl ester in free and liposomal formulations for the photosensitization of tumor organ cultures. Br J Cancer. 2002;86(8):837-842.

14. Casas A, Batlle A. Aminolevulinic acid derivatives and liposome delivery as strategies for improving 5-aminolevulinic acid-mediated photodynamic therapy. Curr Med Chem. 2006;13(10):1157-1168.

15. Webber J, Kessel D, Fromm D. Side effects and photosensitization of human tissues after aminolevulinic acid. J Surg Res. 1997;68(1):31-37.
16. Casas A, Batlle A, Butler A, et al. Comparative effect of ALA derivatives on protoporphyrin IX production in human and rat skin organ cultures. Br J Cancer. 1999;80(10):1525-1532.

17. Berger Y, Ingrassia L, Neier R, Juillerat-Jeanneret L. Evaluation of dipeptide-derivatives of 5-aminolevulinic acid as precursors for photosensitizers in photodynamic therapy. Bioorg Med Chem. 2003;11(7): 1343-1351.

18. Ludovic BF, Giuntini I, Eggleston M, et al. 5-Aminolevulinic acid peptide prodrugs enhance photosensitization for photodynamic therapy. Mol Cancer Ther. 2008;7(6):1720-1729.

19. Giuntini F, Bourre L, MacRobert AJ, et al. Improved peptide prodrugs of 5-ALA for PDT: rationalization of cellular accumulation and protoporphyrin IX production by direct determination of cellular prodrug uptake and prodrug metabolization. J Med Chem. 2009;52(13):4026-4037.

20. Zhu X, Lu W, Zhang Y, et al. Imidazole-modified porphyrin as a $\mathrm{pH}$ responsive sensitizer for cancer photodynamic therapy. Chem Commun (Camb). 2011;47(37):10311-10313.

21. Pichon C, Goncalves C, Midoux P. Histidine-rich peptides and polymers for nucleic acids delivery. Adv Drug Deliv Rev. 2001;53(1-3):75-94.

22. Benns JM, Choi JS, Mahato RI, et al. pH-sensitive cationic polymer gene delivery vehicle: $\mathrm{N}$-Ac-poly( $L$-histidine)-graft-poly( $L$-lysine $)$ comb shaped polymer. Bioconjug Chem. 2000;11(5):637-645.

23. Delley B. From molecules to solids with the DMol' approach. J Chem Phys. 2000;113(18):7756-7764.

24. Klamt A, Schüürmann G. COSMO: a new approach to dielectric screening in solvents with explicit expressions for the screening energy and its gradient. J Chem Soc Perkin Trans. 1993;2(6):799-805.

25. Andzelm J, Kolmel C, Klamt A. Incorporation of solvent effects into the density functional calculations of molecular energies and geometries. J Chem Phys. 1995;103(21):9312-9320.

26. Vosko SJ, Wilk L, Nusair M. Accurate spin-dependent electron liquid correlation energies for local spin density calculations: a critical analysis. Can J Phys. 1980;58(8):1200-1211.

27. Perdew JP, Wang Y. Accurate and simple analytic representation of the electron-gas correlation energy. Phys Rev B. 1992;45(23): 13244-13249.

28. Delley B. An all-electron numerical method for solving the local density functional for polyatomic molecules. J Chem Phys. 1990;92(1): 508-517.

29. Caimduff FM, Stringer R, Hudson EJ, et al. Superficial photodynamic therapy with topical 5-aminolaevulinic acid for superficial primary and secondary skin cancer. Br J Cancer. 1994;69(3):605-608.

30. Wolf P, Rieger E, Kerl H. Topical photodynamic therapy with endogenous porphyrins after application of 5-aminolevulinic acid. An alternative treatment modality for solar keratoses, superficial squamous cell carcinomas, and basal cell carcinomas? J Am Acad Dermatol. 1993; 28(1):17-21.

31. Rogers LMA, McGivern PG, Butler AR, et al. An efficient synthesis of 5-aminolaevulinic acid (ALA)-containing peptides for use in photodynamic therapy. Tetrahedron. 2005;61(29):6951-6958.

32. Leng QL, Goldgeier J, Zhu P, et al. Histidine-lysine peptides as carriers of nucleic acids. Drug News Perspect. 2007;20(2):77-86.

33. Hadjichristidis N, Iatrou H, Pitsikalis M, et al. Synthesis of well-defined polypeptide-based materials via the ring-opening polymerization of $\alpha$-amino acid $N$-carboxyanhydrides. Chem Rev. 2009;109(11): 5528-5578.

34. Foresman JB, Frisch AE. Exploring chemistry with electronic structure methods. Gaussian Inc Pittsburgh PA. 1996;10(2):237-246.

35. Andres J, Beltran J. Quimica teorica computational. Universitat Jaume, Castellon de la Plana Espana. 2000;17(6):161-173.

36. Tang E, Tommaso DD, de Leeuw NH. Accuracy of the microsolvationcontinuum approach in computing the $\mathrm{pKa}$ and the free energies of formation of phosphate species inaqueous solution. Phys Chem Chem Phys. 2010;12:13804-13815.

37. Mineva T, Parvanov V, Petrov I, et al. Fukui indices from perturbed kohn-sham orbitals and regional softness from Mayer atomic valences. J Phys Chem A. 2001;105(10):1959-1967. 
38. Cruz J, Martinez-Aguilera LM, Salcedo R, et al. Reactivity properties of derivatives of 2-imidazoline: an ab initio DFT study. Int J Quant Chem. 2001;85(4-5):546-556.

39. Karelson M, Lobanov VS. Quantum-chemical descriptors in QSAR/ QSPR studies. Chem Rev. 1996;96(3):1027-1044.

40. Lee ES, Shin HJ, Na K, et al. Poly( $L$-histidine)-PEG block copolymer micelles and pH-induced destabilization. J Control Release. 2003;90(3): 363-374.

41. Schocnteld N, Epstem O, Lahav M, et al. Biosynthetic pathway in lymphocytes of patients with malignant lymphoproliferative disorders. Cancer Lett. 1988;43(1):43-48.

42. Kondo M, Hirota N, Takaoka T, et al. Hemebiosynthetic activities and porphyrin accumulation in normal liver and hepatoma cell lines and rats. Cell Biol Toxicol. 1993;9(1):95-105.
43. El-Sharabasy MMH, El-Wassel AM, Hafez MM, et al. Porphyrin metabolism in some malignant diseases. Br J Cancer. 1992;65(3): 409-412.

44. Kennedy JC, Pottier RH. Endogenous protoporphyrin IX. A clinically useful photosensitizer for photodynamic therapy. $J$ Photochem Photobiol B. 1992;14(4):275-292.

45. Kriegmair M, Baumgartner R, Kneuchel R, et al. Fluorescence detection of neoplastic urothelial lesions following intravesical installation of 5-aminolevulinic acid. Urology. 1994;44(6):836-841. 


\section{Supplementary data}

Novel poly(L-histidine) tagged 5-aminolevulinic acid prodrugs: new photosensitizing precursors of protoporphyrin IX for photodynamic therapy for colon cancer.
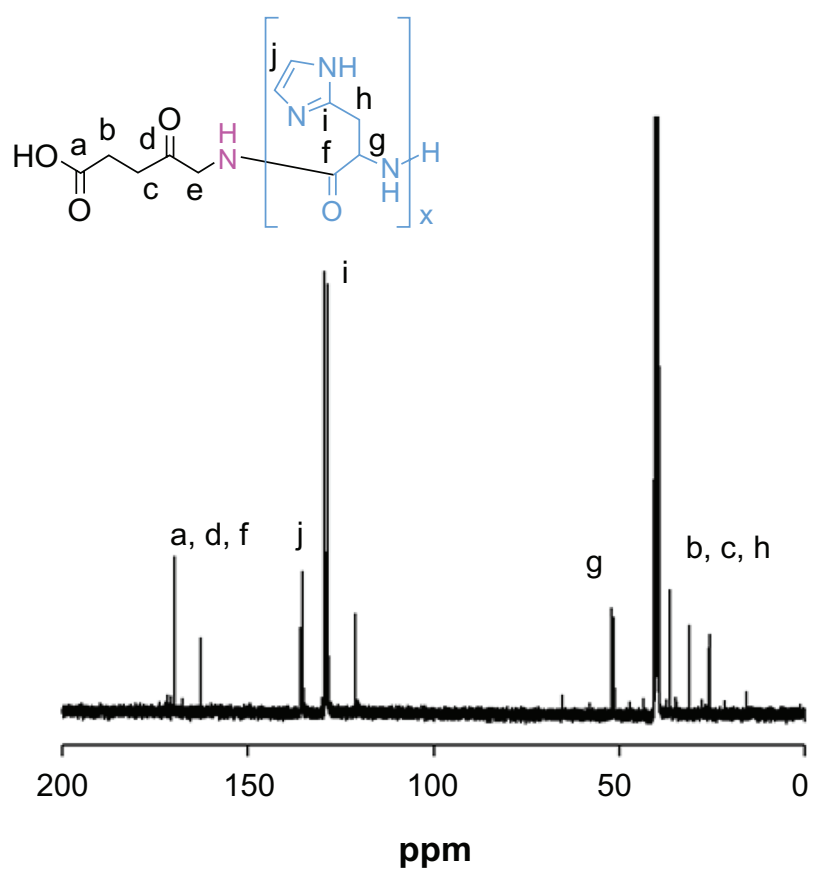

Figure SI ${ }^{13} \mathrm{C}$ nuclear magnetic resonance spectra of ALA-p(His) in dimethyl- $d_{6}$ sulfoxide at $25^{\circ} \mathrm{C}$.

Abbreviation: ALA, 5-aminolevulinic acid.

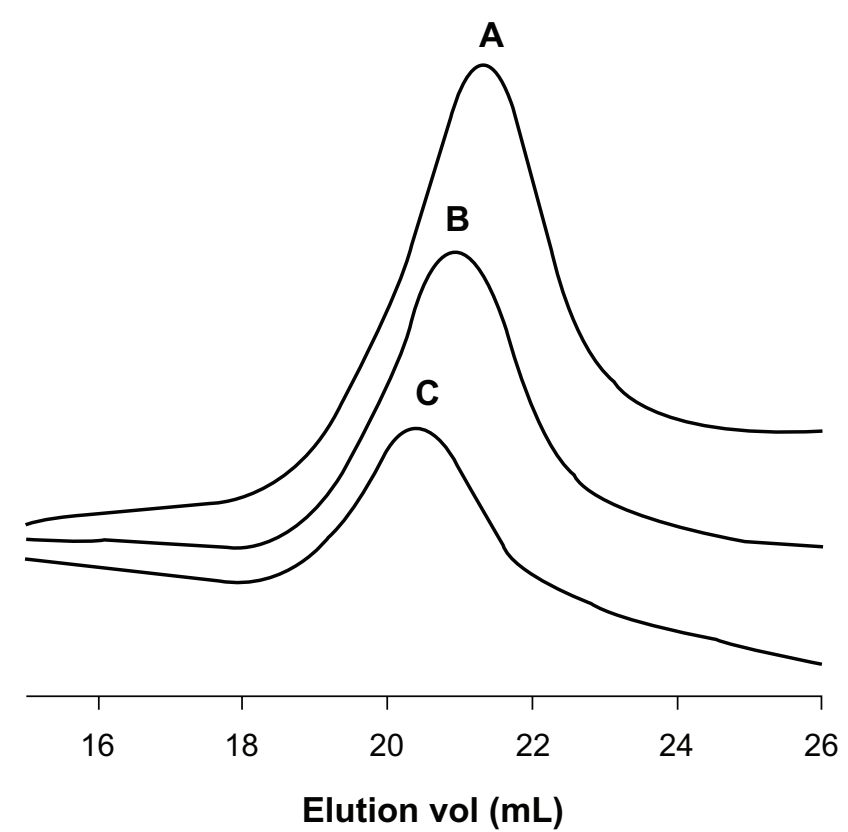

Figure $\mathbf{S 2}$ Gel permeation chromatography traces of (A) ALA-p $(H i s)_{5}$, (B) ALA-p $(H i s)_{10}$, and (C) ALA-p $(H i s)_{15}$.

Note: Increment of molecular weight and monodispersity are clearly visible.

Abbreviation: ALA, 5-aminolevulinic acid. 


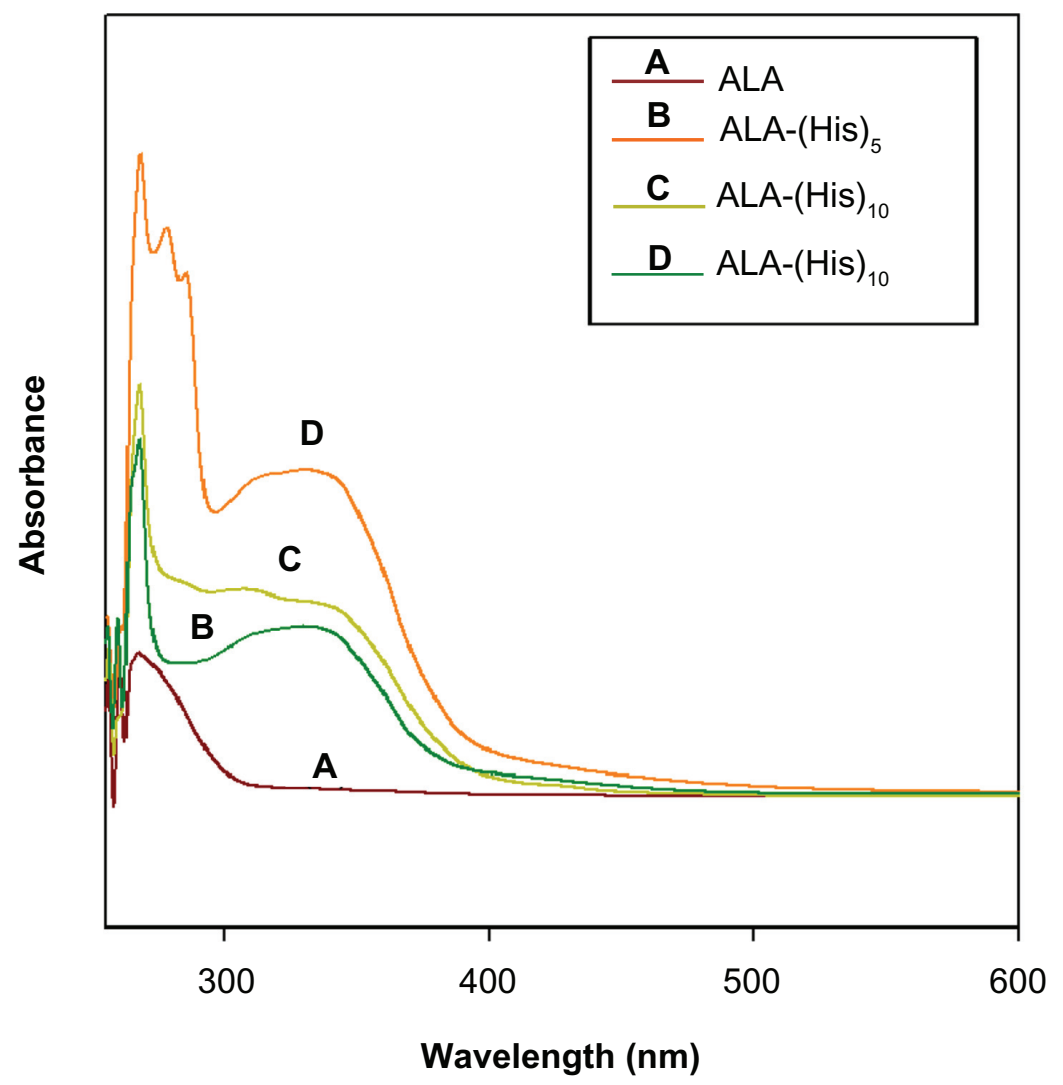

Figure S3 Ultraviolet-visible spectra of ALA $\left(\lambda_{\max } 267 \mathrm{~nm}\right)$ and ALA-p(His) derivatives show two absorption maxima $\left(\lambda_{\max } 267 \mathrm{~nm}\right.$ and $\left.336 \mathrm{~nm}\right)$. Abbreviation: ALA, 5-aminolevulinic acid. 


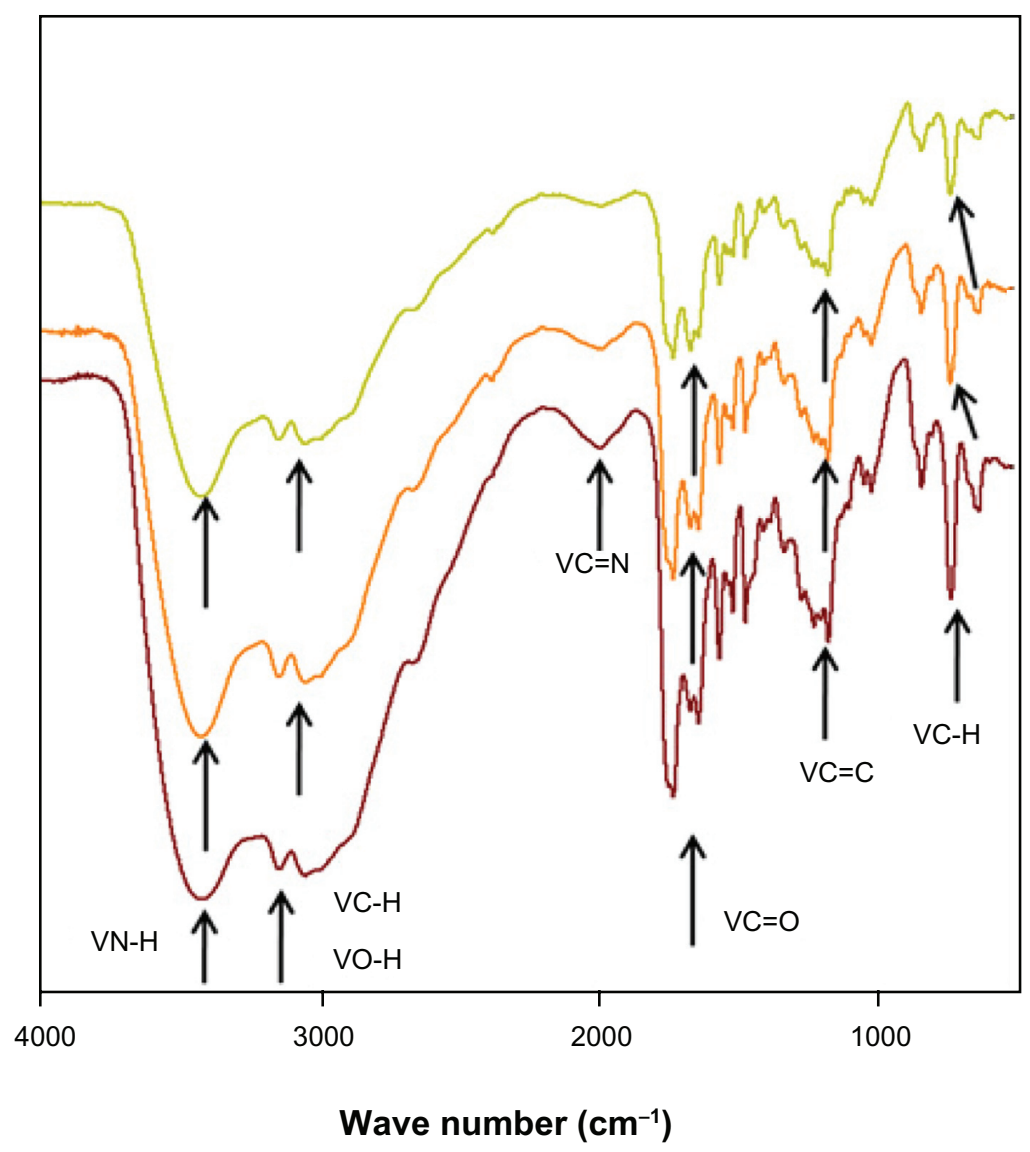

ALA-(His)

ALA-(His) ${ }_{10}$

ALA-(His)

Figure S4 Fourier transform infrared spectra of ALA-p(His) derivatives shows characteristic bond stretching.

Abbreviation: ALA, 5-aminolevulinic acid.

International Journal of Nanomedicine

Dovepress

\section{Publish your work in this journal}

The International Journal of Nanomedicine is an international, peerreviewed journal focusing on the application of nanotechnology in diagnostics, therapeutics, and drug delivery systems throughout the biomedical field. This journal is indexed on PubMed Central, MedLine, CAS, SciSearch ${ }^{\circledR}$, Current Contents ${ }^{\circledR} /$ Clinical Medicine,

Journal Citation Reports/Science Edition, EMBase, Scopus and the Elsevier Bibliographic databases. The manuscript management system is completely online and includes a very quick and fair peer-review system, which is all easy to use. Visit http://www.dovepress.com/ testimonials.php to read real quotes from published authors. 